\title{
美容鍼施術におけるMRI画像評価の検討 一咬筋と表在性筋膜に着目したパイロットスタディー
}

荻野三恵子 ${ }^{1,3)}$ 、長谷川千歳2)、中村 真通 ${ }^{32}$ 、本合 祥哲 ${ }^{4}$ 、阿部浩一郎 ${ }^{5)}$ 、坂本 歩(
1）コウ鍼尒治療院
2）呉竹鍼炎柔整専門学校
3）東京医療専門学校
4）呉竹メディカルクリニック
5）青山研美会クリニック
6）学校法人 呉竹学園

\section{要 旨}

【目的】美容鍼の効果評価は従来、施術者や患者の主観的な評価、血流量や水分量、油 分量の計測などにより行われてきた。一方、近年MRIなどの画像診断装置が、アンチエ イジングや美容の分野にも応用され客観的な画像評価が可能となってきた。そこで、咬 筋を中心に内部構造と顔面容貌にどのような変化がみられるか、MRI画像による評価の 可能性について検討した。

【方法】インフォームドコンセントを得た健康成人女性2名を対象に、ステンレス製 $15 \mathrm{~mm} \cdot 14$ 号鍼を頭部8箇所、12号鍼を顔面部12箇所、頸部6箇所、さらに誘導穴として 合谷と足三里に刺入し、15分間置鍼した。研究対象者Aは約2週間に 1 回の間隔で合計 9 回の鍼施術を行い、MRIを用い2か月後と3か月半後に評価した。研究対象者Bは鍼施術 を8日間連続で行い、その後約 1 週間に 1 回の間隔で合計16回の鍼施術を行った。画像 から咬筋の断面積と表在性筋膜の変化について検討した。

【結果】両研究対象者ともに咬筋の断面積の減少とともに、左右の断面積差が減少し、 さらに後頭部の表在性筋膜群の厚みが減少し形が整ったことが観察された。

【考察】鍼施術により筋組織の牽引や受容器官に刺激を与え、さらに血流増加により筋 膜の流動性が促されたことにより、MRI画像に変化がみられたと考えた。

【結語】美容鍼施術により、咬筋や表在性筋膜といった皮下構造の変化が確認できたこ とから、美容鍼施術がMRIにより評価できる可能性が示唆された。

キーワード：美容鍼、MRI画像、評価、咬筋、表在性筋膜

連絡著者：荻野三恵子 $=160-0022$ 新宿区新宿 1-24-7-313 コウ鍼众治療院

Corresponding Author; Ogino Mieko, Kou Acupuncture Clinic, 313 1-24-7 Shinjuku Shinjuku-ku Tokyo, 160-0022, Japan 受付日：2020年6月10日＼cjkstart受理日：2021年5月24日 


\section{I 。はじめに}

現在、美容医療では咬筋が容貌に与える影響が 認知され、咬筋の減少を目的とした注入治療（ボ トックス®注射）などが行われている。古山ら1) はボッリヌストキシンを用いた形態の治療の中で、 咬筋は最も効果的な部位であり、歯ぎしりや食い しばりの緩和などの問題改善にも有用であるが、 美容領域においては顕著な咬筋による下顎角部の 肥大、いわゆる「エラ」の減少による小顔効果や 顔貌の改善目的で行われることが多いと報告して いる。すなわち、咬筋の肥大は顔面の容貌や感覚 に影響しているため、美容医療において重要な要 素になっていると考えられる。

咬筋の緊張はエラの張り具合や煩の硬さなど顔 面の容貌や感覚に影響し、また咀嚼筋である咬筋 は顎関節症とも密接な関係がある。美容鍼の臨床 において、顎関節症に遭遇する機会は多く、日々 の臨床から顎関節症の治療と美容鍼尒の関係性が あるのではないかと推測される。ここで顎関節症 の鍼治療について調べてみると、福島 ${ }^{2}$ は筋性の 顎関節症治療をする場合、 TCH (Tooth Contacting Habit; 歯列接触㾀)、歯ぎしり、くいしばりによつ て筋活動が立進した咬筋、側頭筋、内側翼突筋の 緊張や、硬結を刺鍼によって除去できれば、顔面 部の痛みや開口障害を改善することは容易である と報告しており、河野 ${ }^{3}$ はスプリントと鍼众によ る顎関節症治療の症例報告で、下関、上関、煩車、 咀嚼筋、上下の舌骨筋群、胸鎖乳突筋などの緊張 状態に応じた経穴、さらに遠隔部位の経穴では合 谷、足三里、三陰交など口腔顎顔面部に関係する 経穴に刺激を与え、治療後には症状消失を報告し ている。また今井 ${ }^{4}$ は肩こりと頭痛を伴う顎関節 症に対する鍼治療において咀嚼筋群および頝肩部 の筋緊張緩和と鎮痛を目的として、圧痛およびト リガーポイントに相当する経穴に刺鍼し、開口時 痛をvisual analogue scale（VAS）で評価したとこ ろ、鍼治療の直後には值が減少し、症状の軽減が 確認できたと述べている。小林 ${ }^{5}$ は顎関節症によ る疼痛に対する鍼众治療の応用として咀嚼筋、側 頭筋、トリガーポイントへ刺鍼及び鍼通電を行い、 疼痛の軽減数值としてペインスケールが治療前 10 に対して治療後は4になり、無痛開口量が術前は
$20 \mathrm{~mm}$ に対して術後は $42.5 \mathrm{~mm}$ となったと報告して いる。

すなわち顔面の容貌の変化に関与する組織は、 咬筋、内側翼突筋など顎の動きに関係する筋肉が 重要であり、痛みや開口障害にもそれらの筋肉が 関与しており、鍼治療で症状緩和が得られている。 そのため鍼治療で生じる内部組織の変化を画像で とらえることができれば、その効果について客観 的評価が得られるのではないかと推察される。

美容鍼众についてはしわ、くすみ、たるみの改 善やリフトアップなど、さまざまな効果が謳われ、 施術テクニックも多様化する中、幅広い年齢層に 認知され多くの人が施術を受けている。山崎ら は美容鍼の効果について血流判定装置（PeriCam PSI）を用い測定することで、血液量増加が認め られたと報告している。また吉山ら”は顔面部鍼 刺激が顔面部にうるおいを与える影響で鍼施術は 水分量とオイルへ影響させ、皮膚状態のうるおい が皮膚の柔軟性を促進させる可能性を報告してい る。さらに吉山ら ${ }^{8)}$ は顔面部に鍼通電を行い、た るみの引き上げ、水分量、油分量の保持を報告し ている。上坂ら ${ }^{91}$ は鍼施術は主観的評価として乾 燥感の改善を報告している。上述したように面部 血流の変化や保湿作用等の効果についての報告は 散見される。しかしながら顔面容貌に関しては見 た目での主観的評価にとどまり、鍼刺激が内部構 造に及ぼす変化を客観的に評価した報告はみられ ない。

奥田ら ${ }^{10}$ はCTやMRIの画像所見により表情筋、 表在性筋膜群（Superficial Musculo-Aponeurotic System : 以下 SMAS)、顔面の勒帯、脂肪体など の顔面構造物を描出することを試みCTやMRIな どの画像診断は、非侵襲的に皮下の内部構造の状 態を見ることが可能であり、エイジングを解剖学 的に考えるために有用であると述べている。

そこで、今回我々は美容銊众の効果を評価する 上で、咬筋を中心とした顔面容貌の変化とSMAS の変化に着目し、鍼施術後のMRI画像解析を試み た。 


\section{II. 方 法}

1. 対象

対象は本研究について、口頭および書面によるイ ンフォームドコンセントを得た健康成人 2 名（研 究対象者A：30代女性 研究対象者B：50代女性） とした。なお本研究は、事前に吳竹学園研究倫理 委員会による倫理審査（受理番号：17-001）を受 けた後に実施した。

\section{2. 方 法}

(1) 施術頻度と測定時期

施術頻度による変化の違いを検討するため、研 究対象者 $\mathrm{A}$ 研究対象者Bについて以下の通りと した。

1）研究対象者A

継続施術の効果を検討するため、鍼施術を約2 週間に1回の間隔で合計9回の鍼施術を行なつた。 評価は2か月後（5回施術後）及び3か月半後（9回 施術後）に行つた。

2）研究対象者B

鍼施術を8日間連続で行つた。その後、約1週間 に1回の間隔で合計16回の鍼施術を行った。評価 は1週間後（8回施術後）及び3か月後（16回施術 後)に行った。
（2）刺鍼部位および刺激方法

頭部は神庭（GV24）、頭臨泣（GB15）、懸顱 (GB5)、卒谷（GB8）、百会（GV20）を用いた。 顔面部は聴会（GB2）、下関（ST7）、顴髎（SII8）、 地倉（ST4）、魚腰（奇穴）、四白（ST2）を用いた。 頸部は天容（SII7）、鷖風（TE17）、鷖明（奇穴） を用いた（図1）。誘導穴としての足三里（ST36）、 合谷（LI4）を用いた。

鍼刺激はセイリン社製ステンレス鍼 $15 \mathrm{~mm} 14$ 号 を用い、誘導穴、頭部の順に刺銊した。次にセイ リン社製ステンレス鍼 $15 \mathrm{~mm} 12$ 号を用い、顔面部 に深さ $5 \mathrm{~mm}$ の刺入を頭蓋骨の骨上に沿つて横刺 を行つた。頭部と顔面部の方向は全て百会穴に向 かい行い 15 分間置鍼した。

（3）刺鍼部位の選択理由とリスク管理について 今回の研究では、通常臨床で用いる顔面・頭部 の経穴に刺鍼した。その選穴理由は以下の通りで ある。神庭（GV24）、頭臨泣（GB15）は額の㱀 など筋緊張緩和を目的に前頭筋部に選穴した。懸 顱（GB5）、卒谷（GB8）は側頭筋にあり顔面筋 の接続性があることや、咀嚼に関わる筋肉部位で あり、顔面輪郭に影響すると考え、顔面輪郭の引 き上げを目的とした。百会（GV20）は帽状腱膜 にあり、前頭筋と接続されているので前頭筋の緊 張改善を目的に選穴した。

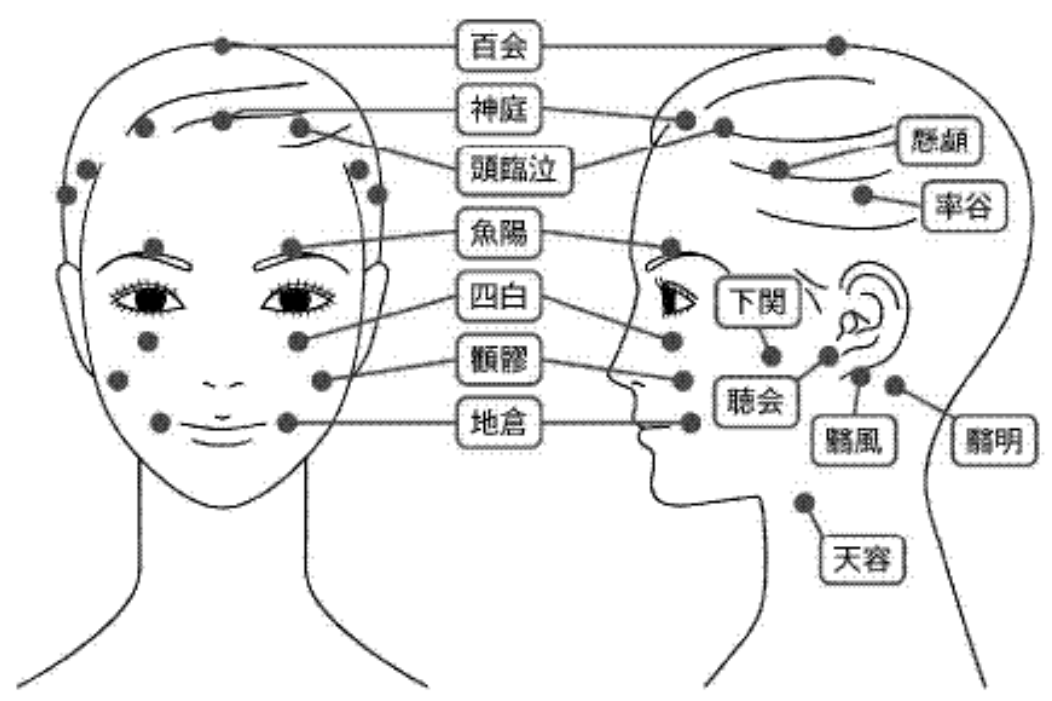

図1 刺鍼部位 
顔面経穴の聴会（GB2）、下関（ST7）は咀嚼 筋の緊張の緩和を目的に、天容（SII7）は胸鎖乳 突筋の前部にあり舌骨の位置にあり、舌骨は舌骨 上筋群につながり顔面輪郭に影響すると考え選穴 した。顴髎（SII8）は咬筋の起始部であり、咬筋 緊張の緩和を目的に、地倉（ST4）は口輪筋にあ り、深部には㚘筋に繋がり、口の開閉障害の改善 及び噛み締めになどによる咬筋緩和を目的に選穴 した。魚腰（奇穴）は前頭筋と㱀眉筋にあり目の 開閉に関わり前頭筋緊張の緩和を目的に、四白 （ST2）は顔面リンパ節と㚘部脂肪体の上にあり 顔面リンパへの刺激を目的に選穴した。

頸部経穴の毉風（TE17）、毉明（奇穴）は胸鎖 乳突筋にあり、咀嚼筋の関連筋肉への弛緩を目的 として選穴した。

誘導穴としての足三里と合谷について、山崎( らは下肢（足の三里）と上肢（合谷と手の三里） の刺鍼により㚘頁と額の血流量が増加し、顔面部位 のみの刺鍼より血流量が少なかったとの報告して いることから、顔面への血流が集中することを防 ぎ出血リスク回避を目的とした。また、刺鍼深度 を5mmとした理由についても、山㟝らのの血流増 加の結果を鑑夕設定した。さらに、Macchi Vら ${ }^{11)}$ は放射線画像（MRI，CTなど）におけるSMASの 外観を分析し㚘頁の領域では低密度表在性線維組織 （SAT）は5.57士 $1.17 \mathrm{~mm}$ 、低密度深部脂肪組織 （DAT）ではより薄く $2.94 \pm 0.62 \mathrm{~mm}$ であると報告 している。刺鍼部位によるが5mmの刺鍼で浅層 筋膜に刺激を与えられるのではないかと考えた。

(4) 評価

MRI（GE社製 HDxt 1.5T）を用い、 T1強調画 像で鼻根部から橋の上部付け根を結んだラインを 基準線に設定し、スライス厚 $3 \mathrm{~mm}$ 間隔の横断面 にて撮影した。測定は解析ソフト（Plissimo VIEW Lite Panasonic Medical Solutions Ltd) を 用いた。

画像上の咬筋ボリュームが明確に視認できる位置 として両側との咬筋上縁から $25 \mathrm{~mm}$ 尾側を選定し 左右の咬筋の断面積を、コンピュータ上で算出し た。さらに後頭部にあるSMASを観察した。

表1 研究対象者AのMRI画像左右咬筋の断面積測定の推移

評価は初回（施術前）、2か月後（5回施術後）、3か月半後（9回施術後）に行った。

\begin{tabular}{|c|c|c|c|}
\hline & 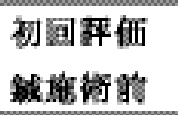 & 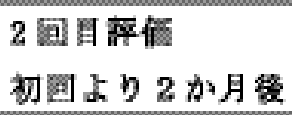 & 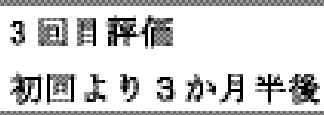 \\
\hline 右 & $353.47 \mathrm{~mm}$ & $361.11 \mathrm{med}$ & $368.26 \mathrm{~mm}^{\prime}$ \\
\hline 左 & $376,98 \mathrm{~mm}^{2}$ & $369,32 \mathrm{met}^{\prime}$ & 364,29 ant' \\
\hline
\end{tabular}

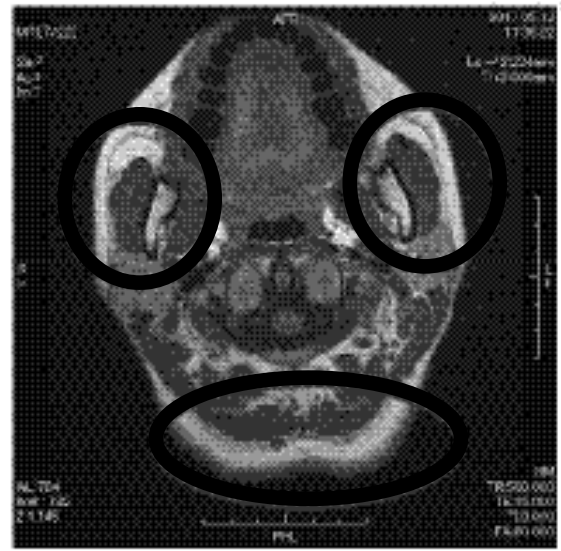

図2 研究対象者Aの初回（左）之最終回（右）

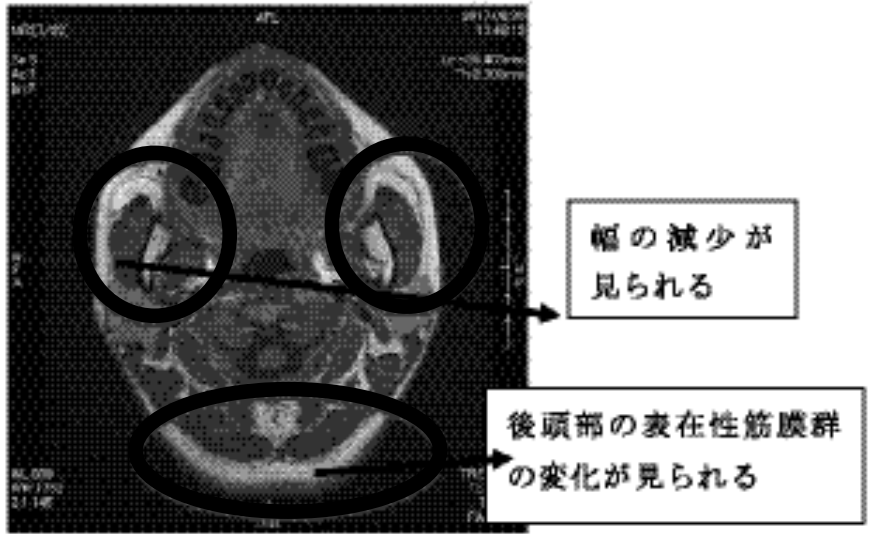

のMRI画像 
表2 研究対象者BのMRI画像左右咬筋の断面皘測定の推移

評価は初回（施術前）、1週間後（8回施術後）、3か月後（16回施術後）に行った。

\begin{tabular}{|c|c|c|c|}
\hline & 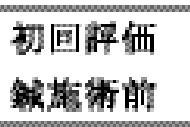 & $\begin{array}{l}2 \text { 回目释值 } \\
\text { 初回上り1週阙後 }\end{array}$ & $\begin{array}{l}3 \text { 回目释低 } \\
\text { 初回上り } 3 \text { か月後 }\end{array}$ \\
\hline 右 & 743.14 maí & 739. $88 \mathrm{~mm}^{\prime}$ & $731.72 \mathrm{~mm}^{2}$ \\
\hline 左 & 738. $55 \mathrm{~mm}^{\prime}$ & $736.07 \mathrm{~mm}^{2}$ & $729.98 \mathrm{mand}$ \\
\hline
\end{tabular}
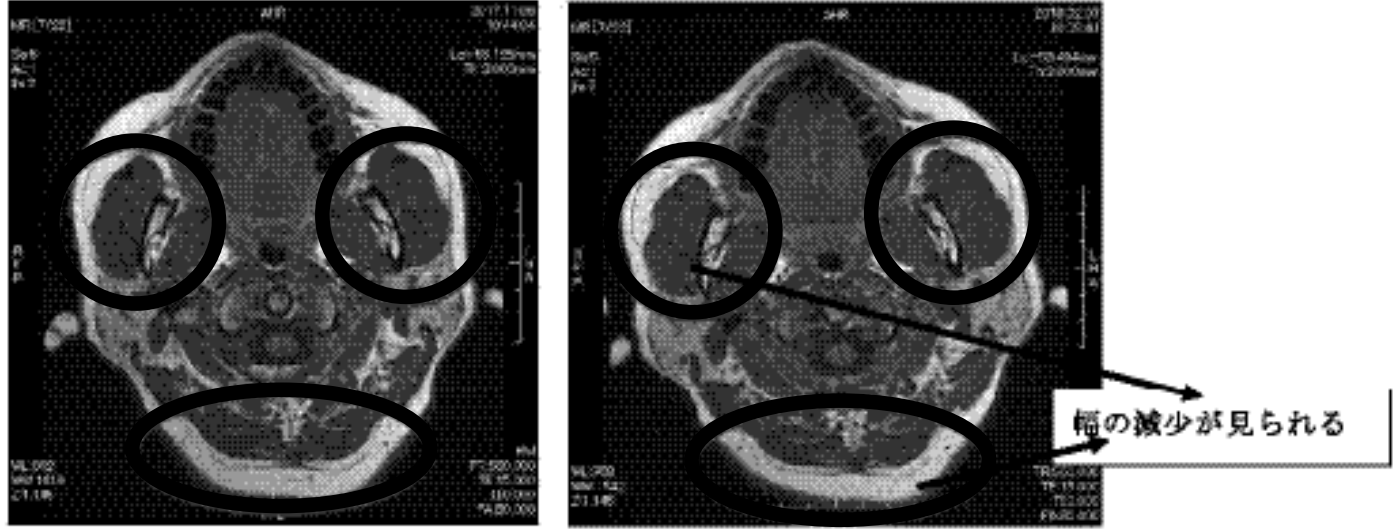

図3 研究対象者Bの初回（左）と最終回（右）のMRI画像
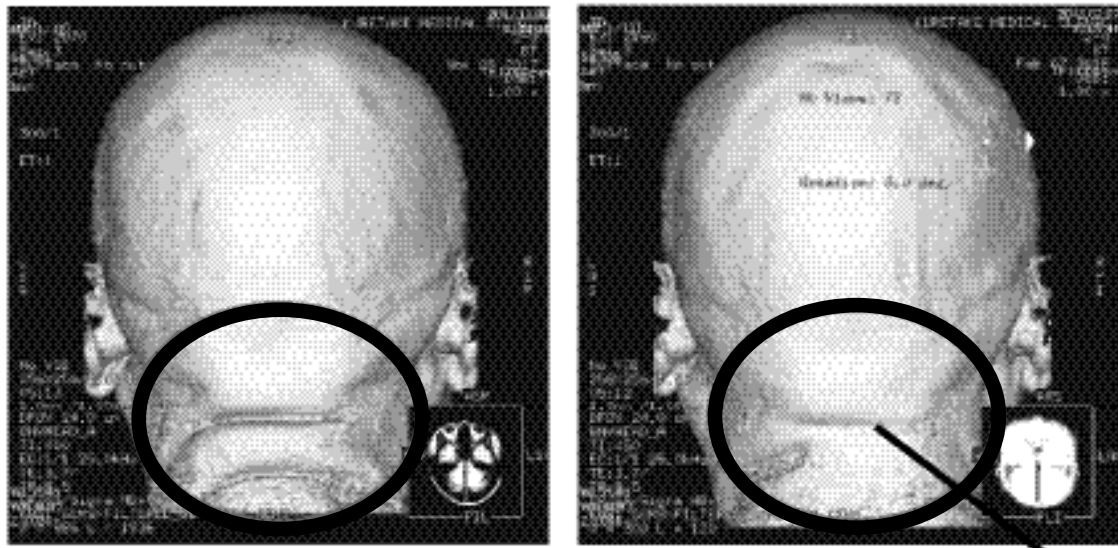

図4 初回（左）と最終回（右）の後頭部SMAS三次元画像

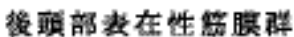
が初圆 2 雷だが最終 回 1 屏になっている。

III. 結 果

1. 研究対象者Aの変化

約2週間に1回の鍼施術を行った研究対象者Aに おいて、初回撮影時の咬筋の面積は右側が353.47 $\mathrm{mm}^{2}$ 、左側が376.98mm 2 であり、左右差が23.51 $\mathrm{mm}^{2}$ あった。2か月後（5回施術後）の撮影時には 右側は $361.11 \mathrm{~mm}^{2}$ 、左側は $369.32 \mathrm{~mm}^{2}$ となり、右 側咬筋は $7.64 \mathrm{~mm}^{2}$ 増加となり、左側咬筋は7.66 
$\mathrm{mm}^{2}$ 減少となつた。3か月半後（9回施術後）の最 終回撮影時には右側は $358.26 \mathrm{~mm}^{2}$ 、左側は354.29 $\mathrm{mm}^{2}$ となり、左右差は $3.97 \mathrm{~mm}^{2}$ となった。初回と 最終回の左右差を比較すると数值は $19.54 \mathrm{~mm}^{2}$ 減 少した（表1）。初回の後頭部のSMASでは凸凹と 波があるが、最終回にはSMASが減少し形も整つ た（図2）。

\section{2. 研究対象者Bの変化}

鍼施術を 8 日間連続で行った研究対象者Bにお いて、初回撮影時の咬筋の面積は右側が743.14 $\mathrm{mm}^{2}$ 、左側が738.55 $\mathrm{mm}^{2}$ であり、左右差は $4.59 \mathrm{~mm}^{2}$ あった。1週間後（8回施術後）の撮影時は右側が $739.88 \mathrm{~mm}^{2}$ 、左側が $736.07 \mathrm{~mm}^{2}$ であり、初回より 右側咬筋が $3.26 \mathrm{~mm}^{2}$ 、左側咬筋が $2.48 \mathrm{~mm}^{2}$ と左右 共に微減した（表2）。

その後、約 1 週間に 1 回の間隔で鍼施術を行なつ た3か月後（16回施術後）の最終回撮影時には、 右側が731.72 $\mathrm{mm}^{2}$ 、左側が729.98 $\mathrm{mm}^{2}$ であり、初 回に比べ減少し、左右差についても初回が4.59 $\mathrm{mm}^{2}$ であったのに対し、最終回は $1.74 \mathrm{~mm}^{2}$ と減少 した (図3)。

初回と最終回の咬筋と後頭部のSMASの変化を 示す(図4)。

初回の後頭部のSMASの三次元画像では脂肪層 が2層あったが、最終回には1層に減少し形が整つ た。

\section{IV. 考 察}

1. 画像所見による変化とその効果機序について

今回、両研究対象者ともに咬筋の面積の減少と ともに、左右の面積差が減少し、さらに後頭部の SMASの厚みが減少し形が整つたことが観察され たことから、美容鍼施術についてMRI画像で評価 可能であることが示唆された。

咬筋の面積と左右差の減少については、先行研 究による報告の通り、鍼刺激による血流量増加や 筋緊張の緩和により強い噛み締めなどを軽減させ、 咬筋の左右差が減少したのではないかと考える。

後頭部のSMASの厚みの減少と形状変化につい

て、胸鎖乳突筋は胸骨部と鎖骨から起こり乳様突 起、後頭骨および上項線の外側に付着する。後頭
部に刺鍼せず、表在性筋膜群の変化が現れたのは 毉風（TE17）毉明（奇穴）天容（SII7）が胸鎖乳 突筋へ刺激を与え作用したのではないかと考える。

H.M Langevinら ${ }^{12}$ は筋肉や臓器を取り巻く皮下 および結合組織は全身に連続的なネットワークを 形成し、筋膜にある血管や神経の通り道は多くの 経穴の下にあり、鍼療法における刺激は筋組織を ある程度牽引し、受容器官に刺激を与えることに より、皮下結合組織の変形を引き起こすことを報 告している。今回、頭部と胸鎖乳突筋の刺銊が後 頭部の血流増加と筋膜の流動性を促がし、後頭部 におけるSMASの形状変化が確認されたのではな いかと推測される。

\section{2. 咬筋の減少の左右差について}

咬筋の筋肉量の増加は心因性ストレスによる歯 ぎしり、パソコンなどの作業性やスポーツによる 噛みしめなど日常生活における様々な要因が影響 している。これらが顔面の顎の歪みや、片側の煩 のたるみなどの原因になりうる。一般的に左右の 顔のバランスが整うことは均整の取れた美しい顔 として認識されているが、研究対象者の咬筋のバ ランスが整ったことは顔面の歪み、㚘頁のたるみ、 鼻唇溝の変化に影響し、美を求める患者の要望に 応えられる可能性があるのではないかと考えた。

研究対象者Aは2回目測定において右側咬筋の 増加が現れたが、上述の要因が考えられるものの、 定期的な銊施術により最終的には左右のバランス が整つていくものと推察される。

\section{3. 施術頻度と咬筋断面積の变化}

今回2名の研究対象者に対し、2週間に1回、8日 間連続と1週間に1回の鍼施術と頻度を変えた施術 でMRI画像を検討したが、その変化に大きな差は 見出だせなかった。すなわち美容施術は毎日とい うより、1週間から2週間に1回継続的な施術を行 うことで変化がみられる可能性が示唆された。

\section{V. 結 語}

本研究はMRI画像評価の可能性を検討するパイ ロットスタディとして、2症例について銊刺激に よる咬筋断面積の変化を観察した。この研究によ 
り皮下構造の変化がMRIによって画像としてとら えることが確認され、今まで客観的に評価が困難 であった美容鍼のエビデンスを解明する方法とし て期待できると考えられた。今後、研究対象者数 を増やしデータの集積を行うとともに、さらに解 析の精度を高めていきたい。

\section{謝 辞}

本調査にあたりご協力いただいた研究対象者、 貴重なご助言戴きました国際医療福祉大学三田病 院放射線診断センター奥田逸子先生に感謝いたし ます。

\section{利益相反}

全ての著者は開示すべき利益相反はない。

\section{文 献}

1）古山登隆, 井上香. ボトックスの進歩. White. 2019; $17(1): 21-30$.

2）福島厚。顎関節症に対する鍼众治療. 医道の 日. $2015 ; 74(7): 93-101$.

3）河野渡. スプリントと鍼众による顎関節治療. 医道の日. 2003；62(8): 22-5.

4）今井賢, 伊藤和憲, 北小路博司, 森西誠, 大 藪秀明. 肩こりと頭痛を伴う顎関節症に対す る銊治療. 医道の日. 2003; 62(8): 26-9.

5）小林麻美．顎関節症による疼痛に対する鍼尒 治療の応用. 医道の日. 2003；62(8)：41-3.

6）山﨑さつき, 安野富美子, 古賀義久, 坂井友 実. 顔面部血流に与える鍼刺激の影響につい て. 全日鍼尒会誌. 2018；68(2)：104-12.

7）吉山美仁, 久下浩史, 辻あゆみ, 南方克之, 辻涼太, 古田高征, 他. 顔面部鍼施術が顔面 部のうるおいに与える影響. 全日鍼众会誌. 2018; $68(2)$ : 113-9.

8）吉山美仁，久下浩史，辻涼太. 顔面部に対す る鍼施術が水分量、油分量、顔検査票に与え る影響. 全日鍼众会誌. 2018；68(4)：257-64.

9）上坂梨沙，山㟝翼，佐藤万代，矢野忠. 鍼施 術および鍼施術と芳香浴との併用が乾燥肌に 与える影響 一角質水分量および水分蒸散量を 指標として-. 日本未病システム学会雑誌.
2012；18(3): 17-24.

10）奥田逸子, 秋田恵一. 放射線診断学から見た アンチエイジング. 形成外科. 2018；61(3): 307-15.

11) Macchi V, Tiengo $C$, Porzionato A, Stecco $C$, Galli S, Vigato E, et al. Anatomo-radiological study of the superficial musculo-aponeurotic system of the face. Ital J Anat Embryol. 2007; $112(4)$ : 247-53

12) Helene $M$ Langevin, Nicole A Bouffard, Gary J Badger, James C Iatridis, Alan K Howe. Dynamic fibroblast cytoskeletal response to subcutaneous tissue stretch ex vivo and in vivo. Am J Physiol Cell Physiol. 2005; 288 (3) : C747-56. 
Research Report

\title{
Evaluation of cosmetic acupuncture from MRI imaging: A pilot study focusing on the masseter muscle and superficial fascia
}

\author{
OGINO Mieko ${ }^{1,3)}$, HASEGAWA Chitose ${ }^{2)}$, NAKAMURA Masamichi" ${ }^{3)}$, \\ HONGOU Yoshinori ${ }^{4)}$, ABE Koichiros), SAKAMOTO Ayumi ${ }^{6}$ \\ 1) Kou Acupuncture Clinic \\ 2) Kuretake School of Oriental Medicine \\ 3) Tokyo Therapeutic Institute \\ 4) Kuretake Medical Clinic \\ 5) Aoyama Beauty Research Clinic \\ 6) Kuretake College of Medical Arts \& Science
}

\begin{abstract}
[Objectives] The effects of cosmetic acupuncture are based on subjective evaluations of acupuncturists and/or patients, satisfaction levels, measurements of blood flow, moisture content and sebum content. Also, with diagnostic imaging now readily available in the fields of antiaging therapy and cosmetic treatment, objective measurements can be made to evaluate the effects of treatment. This study examined magnetic resonance imaging (MRI) scans before and after cosmetic acupuncture to detect changes in appearance and the internal structure of the face, focusing mainly on the masseter muscle.

[Methods] Two healthy women (volunteers A and B), who provided informed consent, underwent acupuncture treatment using $15 \mathrm{~mm}$ No. 14 stainless needles at eight head acupressure points and No. 12 needles at 12 facial acupoints. Six neck acupoints, and LI-4 (Hegu) and ST-36 (Zusanli) were used for induction. Needles were left in place for $15 \mathrm{~min}$. Volunteer A underwent nine sessions at roughly two-week intervals, and the effects of therapy were evaluated using MRI at two months and 3.5 months after therapy. Volunteer B underwent a total of 16 sessions (once daily for eight consecutive days, followed by approximately weekly sessions). Changes in areas of the masseter muscle and morphological changes in the superficial musculoaponeurotic system (SMAS) on MRI images were examined.

[Results] Both volunteers showed decreased masseter muscle areas and smaller differences in the masseter muscle areas between the right and left sides after cosmetic acupuncture. Also, thickness of the SMAS at the back of the head was reduced so that both subjects had a more well-balanced appearance.

[Discussion] It is likely that changes were observed on MRI images because acupuncture stimulated traction of muscle tissue and receptors, and increased blood flow improves fluidity of the fascia.

[Conclusion] MRI revealed subcutaneous structural changes (e.g., changes in the masseter muscle and SMAS caused by cosmetic acupuncture, indicating MRI can be used to assess the effects of cosmetic acupuncture.
\end{abstract}

Zen Nihon Shinkyu Gakkai Zasshi (Journal of the Japan Society of Acupuncture and Moxibustion: JJSAM). 2021; 71(3): 130-137. Received 10 Jun, 2020 Accepted 24 May, 2021

Key words: cosmetic acupuncture, magnetic resonance imaging, assessment, masseter muscle, superficial musculoaponeurotic system 